\title{
Clinical and ultrastructural observations in a kindred with normo-hyperkalaemic periodic paralysis*
}

T. S. DANOWSKI, E. R. FISHER, C. VIDALON, J. W. VESTER, R. THOMPSON, S. NOLAN, T. STEPHAN, and J. H. SUNDER

From the Institutes of Pathology and Graduate Medicine of Shadyside Hospital, Pittsburgh, the Good Samaritan Hospital, Cincinnati, the Departments of Pathology and Medicine of the University of Pittsburgh School of Medicine, and the Department of Medicine, Cincinnati College of Medicine, USA

Summary. Electron microscopic studies of muscle biopsies from clinically unaffected sibs in a family with normo-hyperkalaemic periodic paralysis with variable myotonia have revealed dilatation of the sarcoplasmic reticulum similar to that observed in affected members. This supports the view that such dilatation is not only a significant and likely primary ultrastructural change but that it may precede clinical manifestations and represent an anatomical marker of the genetic trait.

Identical dilatation of the sarcoplasmic reticulum was found in the clinically unaffected father of the affected and unaffected grandchildren of the propositus. This raises the possibility that this non-consanguineous member contributed to the genetic trait or its manifestations in the grandchildren of the index patient since similar dilatation of the sarcoplasmic reticulum was not observed in the muscles of healthy control subjects.

I

II<smiles>CCOc1ccccc1</smiles>

II<smiles>COCCO</smiles>

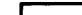
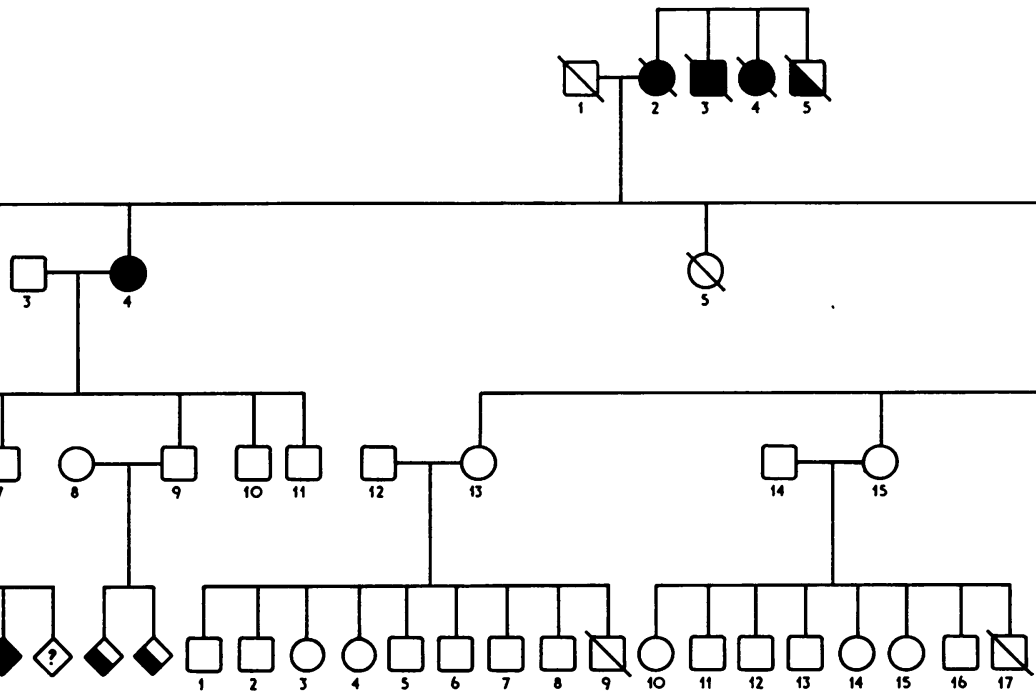

(all well)

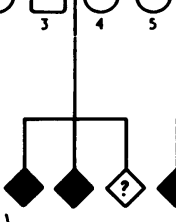

....

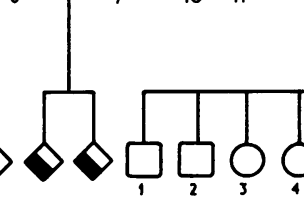


TABLE I

PERIODIC PARALYSIS IN THE PROPOSITUS, HIS DAUGHTER, AND HIS GRANDCHILDREN

\begin{tabular}{|c|c|c|c|c|c|c|c|}
\hline$\cdot$ & II.6 & III.17 & IV.18 & IV.19 & IV.20 & IV.21 & IV.24 \\
\hline $\begin{array}{l}\text { Sex } \\
\text { Present age (yr) } \\
\text { Onset age (yr) } \\
\text { Frequency (per yr) } \\
\text { Duration }\end{array}$ & $\begin{array}{l}M \\
57 \\
9 \\
2-3 \\
7 \text { days }\end{array}$ & $\begin{array}{l}\mathbf{F} \\
35 \\
2-3 \\
1-2 \\
7 \text { days }\end{array}$ & $\begin{array}{l}M \\
16 \\
3 \\
2-3 \\
1-2 \text { days }\end{array}$ & $\begin{array}{l}F \\
15 \\
2-3 \\
2-3 \\
1-4 \text { days }\end{array}$ & $\begin{array}{l}F \\
13 \\
2-3 \\
2-3 \\
1-4 \text { days }\end{array}$ & $\begin{array}{l}F \\
12 \\
2 \\
12 \\
1-4 \text { days }\end{array}$ & $\begin{array}{l}\text { F } \\
4 \\
2 \\
2-3 \\
2 \text { hours }\end{array}$ \\
\hline $\begin{array}{l}\text { Muscle weakness } \\
\text { Initial } \\
\text { Most marked }\end{array}$ & $\begin{array}{l}\text { Neck } \\
\text { Legs }\end{array}$ & $\begin{array}{l}\text { Neck } \\
\text { Legs }\end{array}$ & $\begin{array}{l}\text { Arms } \\
\text { Legs }\end{array}$ & $\begin{array}{l}\text { Fingers } \\
\text { Legs }\end{array}$ & $\begin{array}{l}\text { Neck } \\
\text { Legs }\end{array}$ & $\begin{array}{l}\text { Legs } \\
\text { Legs }\end{array}$ & $\begin{array}{l}\text { Legs } \\
\text { Legs }\end{array}$ \\
\hline $\begin{array}{l}\text { Precipitating factors } \\
\text { Infection, fever } \\
\text { Exercise } \\
\text { Inclement weather } \\
\text { Anxiety } \\
\text { Food } \\
\text { Drugs } \\
\end{array}$ & $\begin{array}{l}0 \\
0 \\
0 \\
+ \\
\text { Sauerkraut } \\
\text { Pentothal }\end{array}$ & $\begin{array}{l}\mathbf{0} \\
0 \\
+ \\
+ \\
\text { Cantaloupe }\end{array}$ & $\begin{array}{l}+ \\
0 \\
0 \\
+ \\
\text { Oranges }\end{array}$ & $\begin{array}{l}+ \\
0 \\
+ \\
+ \\
0 \\
\text { Cortisone }\end{array}$ & $\begin{array}{l}+ \\
0 \\
0 \\
? \\
0\end{array}$ & $\begin{array}{l}0 \\
0 \\
0 \\
? \\
0\end{array}$ & $\begin{array}{l}\mathbf{0} \\
\mathbf{0} \\
\mathbf{0} \\
\mathbf{0} \\
\mathbf{0}\end{array}$ \\
\hline $\begin{array}{l}\text { Relieved by } \\
\text { Walking } \\
\text { Drugs }\end{array}$ & $\stackrel{+}{?}$ & $\stackrel{+}{\text { Chlorothiazide }}$ & $\stackrel{+}{?}$ & $\stackrel{+}{?}$ & $\stackrel{+}{?}$ & $\stackrel{+}{?}$ & $?$ \\
\hline $\begin{array}{l}\text { Myotonia } \\
\text { Percussion, thenar } \\
\text { Percussion, tongue } \\
\text { Percussion, arms } \\
\text { Cold to eyelids }\end{array}$ & $\begin{array}{l}0 \\
+ \\
0 \\
0\end{array}$ & $\begin{array}{l}+ \\
+ \\
+ \\
\pm\end{array}$ & $\begin{array}{l}+ \\
+ \\
+ \\
+\end{array}$ & $\begin{array}{l}++ \\
+ \\
+ \\
+\end{array}$ & $\begin{array}{l}+ \\
+ \\
+ \\
+\end{array}$ & $\begin{array}{l}+? \\
+ \\
+ \\
+\end{array}$ & \\
\hline Recording ergometry* & Grossly abnormal & Poor & Poor & Poor & Poor & Poor & \\
\hline Other conditions & $\begin{array}{l}\text { Myocardial infarction; } \\
\text { Jiver disease }\end{array}$ & & & & & & \\
\hline
\end{tabular}

* Hand compression of rubber bulb at 1-sec intervals for 105 seconds (Green et al, 1961).

five (IV.18, IV.19, IV.20, IV.21, IV.24) of her seven children. Her husband (III.16) is entirely well; there is no evidence of consanguinity in this marriage.

Clinical manifestations. Muscle atrophy, generalized but most marked in the thighs, was present only in the index patient who reported a substantial and consistent alcohol intake which did not impair his employability. Performance on recording hand ergometry (Green, Rideout, and Shaw, 1961) was distinctly impaired only in him, but an inability to synchronize in this test the compression of the rubber bulb at intervals of $1 \mathrm{sec}$ for $105 \mathrm{sec}$ was noted in all affected members.

Many features of the episodes of paralysis were the same in the six other subjects. Thus, the initial episodes occurred before the age of 10 years and each patient reported one to 12 severe episodes per year in addition to mild attacks at weekly or monthly intervals. The severe attacks began in the morning and lasted from 2 hours to 7 days. The mild attacks usually occurred during the day and lasted only a few hours. Severe as well as mild attacks were often preceded by a heavy feeling and/ or vague sensory disturbances in the extremities.
Weakness was most marked in the legs but the initial manifestations could be in the legs, arms, fingers, or neck (Table I). Precipitating factors were variable or non-existent. Thus, three reported onset during febrile repiratory illnesses, at least four indicated that anxiety or fear could trigger an attack, and two stated that inclement weather preceded some of the severe episodes. A particular food, ie, sauerkraut, cantaloupes, or oranges, was offered as a precipitating factor by three of the members. Pentothal anaesthesia had preceded one or more severe attacks in the propositus and administration of cortisone to IV.19 for poison ivy dermatitis was immediately followed by paralysis. It is to be noted that none indicated that exercise or rest after exercise ever precipitated a severe or a mild attack and all stated they could 'walk off' an impending attack.

Percussion myotonia of the tongue was always present in the family members tested. Other myotonic manifestations, ie, inability to raise the eyelids after application of ice or persistence of muscle contractions on percussion of the forearm or the thenar eminence were demonstrable between paralytic episodes in most of the affected members who were tested (Table I). 
Blood and serum solutes and other laboratory indices. Potassium administration with resultant hyperkalaemia (increase in serum $\mathrm{K}^{+}$from 4.4 to 6.3 $\mathrm{mEq} / \mathrm{l}$.) produced a paralytic attack in the propositus but this test was not performed in the other clinically affected or clinically unaffected family members. Other blood and serum solutes measured between attacks were usually normal in him and in the other affected and two unaffected family members (methods as described by Danowski et al, 1949), but possible clustering of certain values was noted (Table II). Thus, serum chloride levels tended to be high-normal in affected as well as unaffected members. The fasting blood glucose level (Hagedorn and Jensen, 1923) was low, ie, 63 and $59 \mathrm{mg} \%$, in two affected members. Alpha-1 globulin was probably low in the serum protein electropherogram of one affected member $(0.1 \mathrm{~g} \%$ in IV.19) and in one of those not affected $(0.09 \mathrm{~g} \%$ in IV.22). Also, plasma $11(\mathrm{OH})$ corticosteroids (Mattingly, 1962) were 5, 7,6, and $8 \gamma \%$ in the morning in four of the affected subjects and hence lower than is usually observed in a control population (Table II).

Serum CPK levels (Danowski et al, 1968) were definitely increased in three clinically affected members (II.6, IV.20, IV.21) and serum aldolase
(Harris, 1958) was above the upper limit of normal ( 3.0 units) in five of six affected members. The increases in alkaline phosphatase (Kind and King, 1954) above adult ranges occurred in affected and unaffected children but were within the normal range for that age group (Table II). Serum lactic acid dehydrogenase (LDH) was above the upper range of normal, ie, 225 units, only in the propositus (Hochella and Weinhouse, 1965); but serum glutamic oxalacetic transminase (SGOT) (Henry et al, 1960) was above the upper limit of normal, ie, 50 units, in all but one of the affected members.

Though not a member of the family, the same laboratory observations were made in III.16 (Table II). The laboratory findings in III.16 were all within the normal range.

Electron microscopy of muscle biopsies. Using techniques cited earlier and criteria described in previous studies (Fisher, Cohn, and Danowski, 1966), electron microscopic examination of skeletal muscle fibres from six clinically affected members (the propositus, his daughter, and four of her five affected children) revealed mild to moderate dilatation of sarcoplasmic reticulum. One example from IV.19 is shown in Fig. 2. This alteration was

TABLE II

LABORATORY FINDINGS IN AFFECTED AND UNAFFECTED SUBJECTS

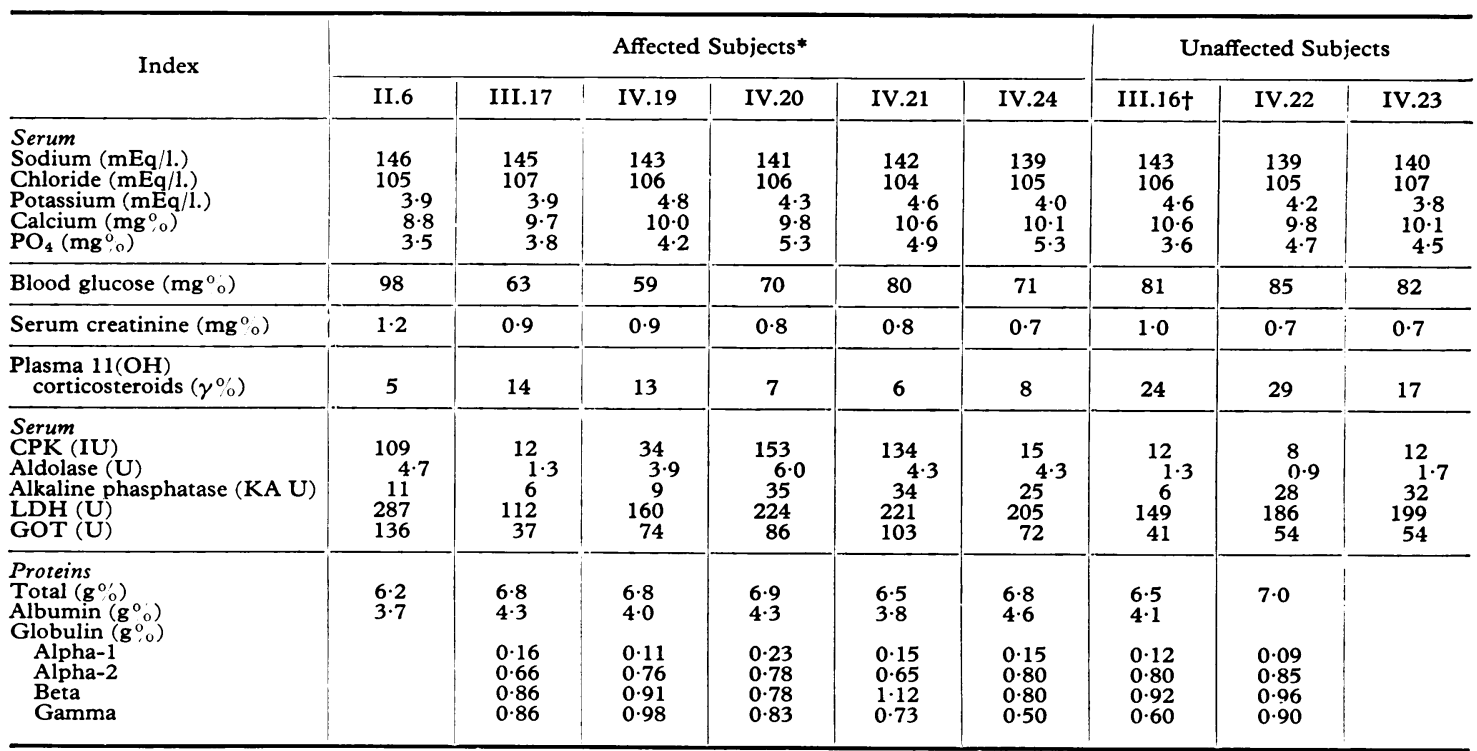

* Similar data and muscle biopsy are not available for the oldest affected child, IV.18.

t Clinically normal son-in-law of the propositus, husband of III.17, and father of IV.19, IV.20, IV.21, IV.22, IV.23, IV.24, and IV.18 (not shown). 

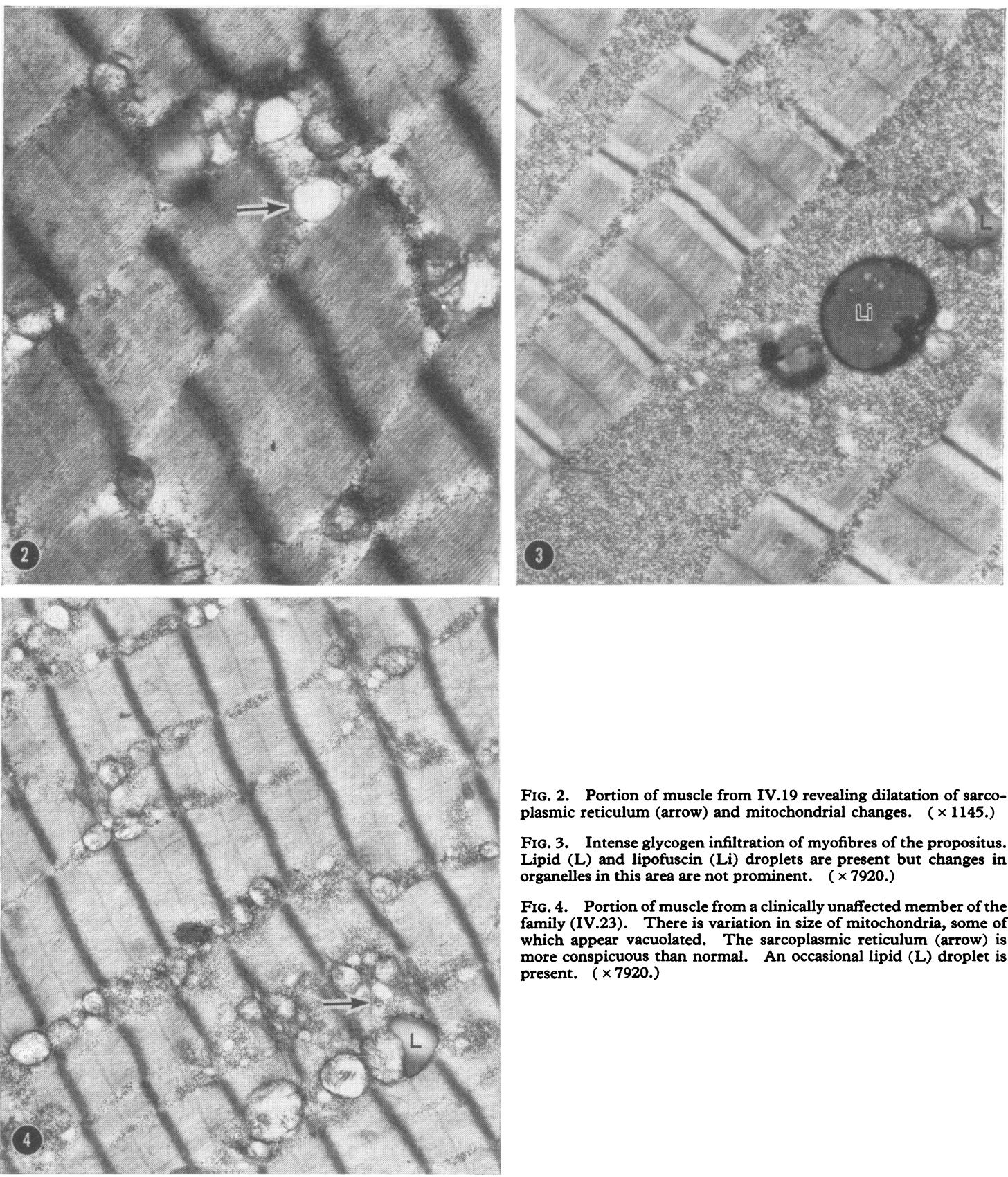

Fig. 2. Portion of muscle from IV.19 revealing dilatation of sarcoplasmic reticulum (arrow) and mitochondrial changes. $(\times 1145$.

FIG. 3. Intense glycogen infiltration of myofibres of the propositus. Lipid (L) and lipofuscin ( $\mathrm{Li})$ droplets are present but changes in organelles in this area are not prominent. ( $\times 7920$.)

FIG. 4. Portion of muscle from a clinically unaffected member of the family (IV.23). There is variation in size of mitochondria, some of which appear vacuolated. The sarcoplasmic reticulum (arrow) is more conspicuous than normal. An occasional lipid (L) droplet is present. ( $\times$ 7920. $)$ 


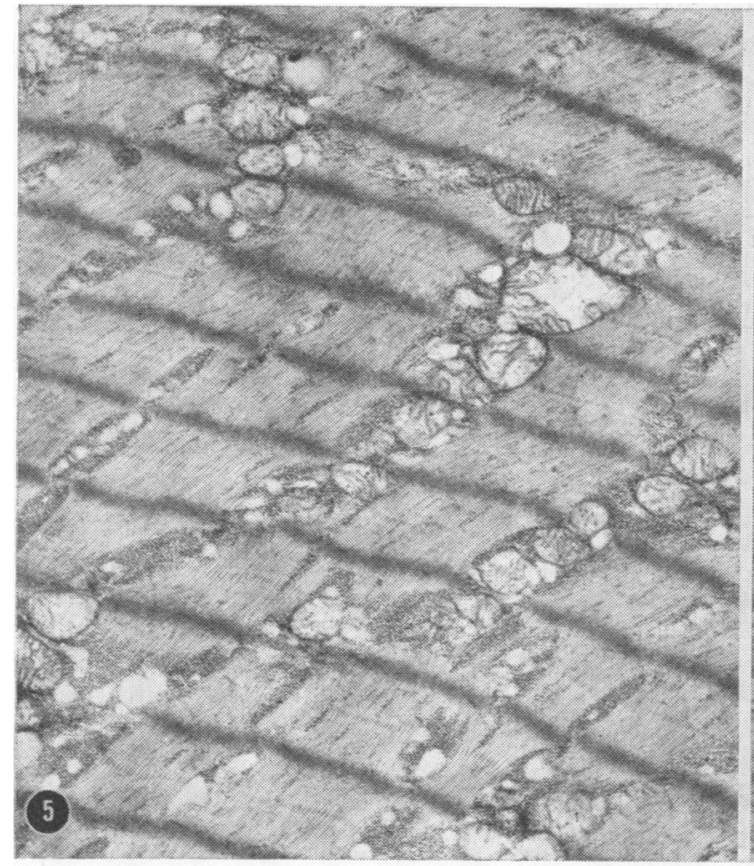

FIG. 5. Dilatation of sarcoplasmic reticulum in III.16. $(\times 7920$.

quantitatively similar in the other affected members regardless of the severity of the disease. In addition, many but not all of these six individuals with a history of paralysis exhibited focal pleoconial and megaconial mitochondrial changes of the type evident in Fig. 2. Glycogen infiltration of myofibres, particularly beneath the sarcolemmal membrane, was intense in some of the biopsy samples (Fig. 3). Lipid and lipofuscin droplets were only occasionally observed.

Dilatation of the sarcoplasmic reticulum was also present in the muscle biopsy specimens from IV.22 and IV.23, two of the clinically unaffected children of the clinically affected daughter, without the associated ultrastructural changes noted in the affected members. An example from IV.23 is shown in Fig. 4. Similar dilatations (Fig. 5) were found in the biopsy specimen from the clinically normal husband (III.16) of the affected daughter. Such dilatation of the sarcoplasmic reticulum was not found in the muscle biopsy specimens from the 20 healthy controls.

In the index patient, occasional fibres exhibited

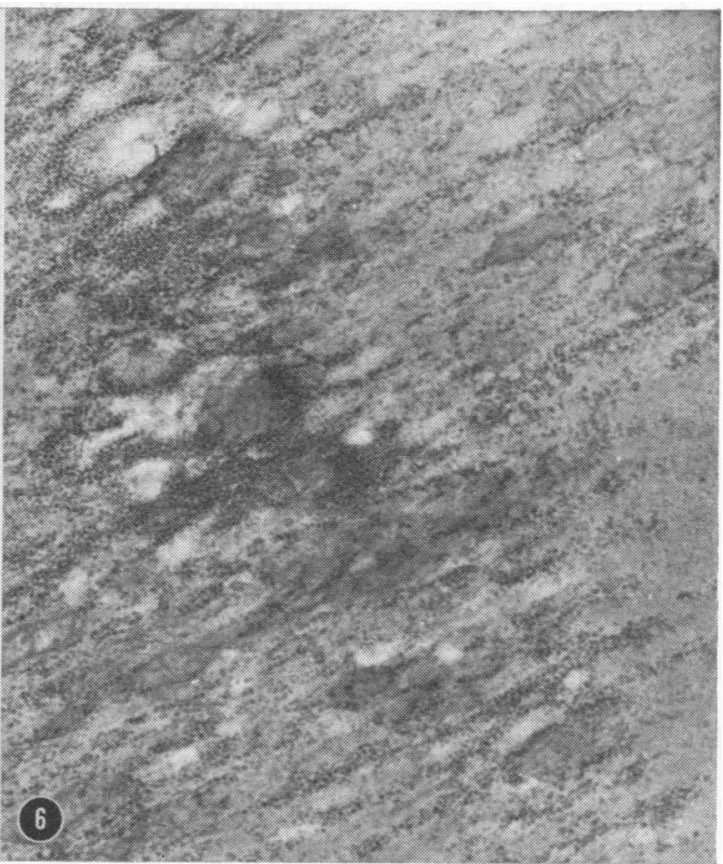

FIG. 6. Discoid degeneration in muscle of III.16., the clinically normal son-in-law of the index patient, in whom similar changes were present. In both subjects, biopsy revealed areas characterized by the presence of glycogen particles and organelles in a matrix of sarcoplasm which lacks sarcomere differentiation. $(\times 18,070$. $)$

discoid degeneration characterized by the presence of organelles and glycogen particles within a matrix of sarcoplasm almost or totally devoid of sarcomere structure. The same type of change was found in III.16 (Fig. 5), the clinically unaffected son-in-law of the propositus, in whom sarcoplasmic dilatation was also present.

\section{Discussion}

The clinical manifestations in this family are in keeping with those reported for normo-hyperkalaemic periodic paralysis (Gamstorp, 1956; Gamstorp et al, 1957; Egan and Klein, 1959; Klein, Egan, and Usher, 1960; Armstrong, 1962; Layzer, Lovelace, and Rowland, 1967; Macdonald, Rewcastle, and Humphrey, 1968; Bradley, 1969; Auböck and Fladerer, 1970; Jeune, David, and de Villard, 1970; Schnaberth and Summer, 1970; Streeten, Dalakos, and Fellerman, 1971). However, in other families, an amelioration of the frequency and severity of the attacks has been noted in the young adult years (Gamstorp, 1956; Armstrong, 1962). 
TABLE III

PERIODIC PARALYSIS: USUAL AS WELL AS 'PARADOXICAL' ACTIONS OF THERAPEUTIC AGENTS

\begin{tabular}{|c|c|c|c|}
\hline Agent & Usual Action & Hyper- and/or Normo-kalaemic & Hypokalaemic \\
\hline Glucose and/or insulin rx & $\begin{array}{l}\text { Decreases serum } \\
\text { increases cell } \mathbf{K}^{+}\end{array}$ & $\begin{array}{l}\text { Usually prevents but may } \\
\text { precipitate (Layzer et al, } \\
\text { 1967) paralysis }\end{array}$ & Precipitates paralysis \\
\hline Adrenosteroid rx & $\begin{array}{l}\text { Decreases serum } \mathbf{K}^{+} \text {;ecreases cell } \mathbf{K}^{+}\end{array}$ & $\begin{array}{l}\text { Usually prevents but may } \\
\text { precipitate (Streeten et al, } \\
\text { 1971) paralysis }\end{array}$ & $\begin{array}{l}\text { Usually precipitates but may } \\
\text { prevent (de Graeff and } \\
\text { Lameijer, 1965) paralysis }\end{array}$ \\
\hline Diuretics : thiazides & $\begin{array}{l}\text { Decrease serum } \\
\text { decrease cell } \mathrm{K}^{+}\end{array}$ & Prevent paralysis & Precipitate paralysis \\
\hline $\begin{array}{l}\text { Carbonic anhydrous inhibitors } \\
\text { (acetazoleamide) }\end{array}$ & $\begin{array}{l}\text { Decrease serum } \mathbf{K}^{+} \text {; } \\
\text { decrease cell } \mathbf{K}^{+}\end{array}$ & Prevent paralysis & $\begin{array}{l}\text { Prevent paralysis (Resnick et al, } \\
\text { 1968; Griggs et al, 1970) }\end{array}$ \\
\hline
\end{tabular}

This to date has not been true of our patients but was reported in the sister of the propositus. It should be noted, however, that in the propositus ethanolism may have contributed to the myopathy and precluded amelioration. The foods suggested as possible antecedents of a paralytic episode are of course high in potassium and could serve as a trigger.

The episode which followed cortisone therapy could have represented a chance association but others have described the paradox of paralysis in the hyperkalaemic type following adrenosteroids or ACTH (Streeten et al, 1971). Assuming that the action of these two agents was mediated solely by the decrease which they produce in extracellular and in body potassium, one would expect them to prevent rather than precipitate paralysis. This and other paradoxical effects in hypokalaemic and normohyperkalaemic periodic paralysis of agents which affect body potassium are summarized in Table III. The latter include the occasional precipitation rather than prevention of paralysis by glucose and/or insulin therapy in the hyper-normokalaemic type (Layzer et al, 1967), the occasional prevention rather than precipitation of paralysis by adrenosteroid therapy in the hypokalaemic group (de Graeff and Lameijer, 1965), and quite consistent prevention rather than precipitation of hypokalemic paralytic episodes by acetazolamide (Resnick et al, 1968; Griggs, Engel, and Resnick, 1970). These paradoxes suggest that the occurrence or non-occurrence of paralytic episodes in the various forms of periodic paralysis is not solely dependent on the levels of potassium.

Moreover, other consistent and inconsistent findings can be cited in the hypokalaemic, hypernormokaelemic, and the Eulenberg subgroups (1886) of paralytic-myotonic muscle disorders. Thus, paralysis can occur in the familial hyperkalaemic form without an elevation of serum potassium (Armstrong, 1962; Bradley, 1969; Jeune et al,
1970). Also, Gamstorp's description of adynamia episodica hereditaria with consistent hyperkalaemia does not include a single instance of myotonia (Gamstorp, 1956) or perhaps one, cited by Drager, Hammill, and Shy (1958) whereas this has been variably present in other kindreds with familial hyperkalaemic periodic paralysis (Layzer et al, 1967; Odor, Patel, and Pearce, 1967, Macdonald et al, 1968). Such myotonia may also occur in hypokalaemic patients (Resnick and Engel, 1967). Similarly, periodic paralysis need not be a feature of Eulenberg's type with myotonia (Woolsey, Nelson, and Rossini, 1969), but, when paralysis does develop, characteristic or consistent serum potassium patterns have not been identified (Drager et al, 1958). This variability establishes that manifestations in these disorders are not consistently and exclusively present in a one or another type of periodic paralysis and may thereby complicate attempts at classification.

Our data based on electron microscopic findings in a family with normo-hyperkalaemic paralysis presented here, together with comparable studies by others in normokalaemic and in hypokalaemic periodic paralyses (Drager et al, 1958; Engel et al, 1965; Engel, 1966 and 1970; Gross, Dexter, and Roth, 1966; Howes et al, 1966; Odor et al, 1967; Macdonald et al, 1968 and 1969; Biczyskowa, Fidzianska, and Jedrzejowska, 1969; Bradley, 1969; Brody and Dudley, 1969; Schutta and Armitage, 1969; Auböck and Fladerer, 1970; Bergman et al, 1970a and b; Dunkle et al, 1970; Gordon, Green, and Lagunoff, 1970; Hofmann and Smith, 1970; Schnaberth and Summer, 1970; Ionescu, Radu, and Nicolescu, 1971; Weller and McArdle, 1971), reveal a similarity of ultrastructural changes in all types. Dilatation of the sarcoplasmic reticulum is common to the hyper-, normo-, and hypokalaemic forms and to Eulenberg's paramyotonia with paralysis and potassium fluctuations. This alteration was 
only moderate in the individuals with and without clinical evidence of periodic paralysis comprising this study. The pronounced cisternal dilatation of sarcoplasmic reticulum (Engel, 1970; Howes et al, 1966; Ionescu et al, 1971), dilatation of the $T$ system (Biczyskowa et al, 1969), or deposits of calcium noted by others (Schutta and Armitage, 1969; Weller and McArdle, 1971) was not observed in our patients. Mitochondrial alterations qualitatively similar to those observed in this pedigree of periodic paralysis have been observed in muscle biopsies of normal controls of comparable age. However, they are quantitatively less striking in the latter population. Also, the frequency as well as quantity of glycogen infiltration appears to be greater in these individuals with periodic paralysis than in controls.

Our data also establish that dilatation of the sarcoplasmic reticulum can be present in clinically normal siblings of persons affected by periodic paralysis. The significance of such dilatations is not clear but they may represent forme fruste examples of the disorder.

The finding of dilatation of the sarcoplasmic reticulum and discoid degeneration in the muscle biopsy of III.16, the son-in-law of the propositus, ie, the husband of the affected daughter and the father of her five clinically affected and two clinically normal children, suggests that he may have contributed to the genetic transmission of the paralytic trait or to its clinical manifestations. This possibility is strengthened by the fact that such dilatation of the sarcoplasmic reticulum was not encountered in any of our 20 control subjects.

Ionescu et al (1971) and others (Engel, 1966; Macdonald et al, 1968; Brody and Dudley, 1969) have commented on whether or not dilatation of the sarcoplasmic reticulum is the initial lesion in various types of periodic paralysis. Also, it has been indicated that the number and size of the sarcoplasmic reticulum vacuoles increases with the duration of the disease (Engel, 1966). Irrespective of whether or not such sarcoplasmic dilatation is the initial lesion, it is clear that all samples of muscle from patients with familial or sporadic periodic paralysis and all of those with associated thyrotoxicosis do manifest this change. We have found only one published exception, a patient with a history of massive licorice ingestion, who did not have dilatation of sarcoplasmic reticulum (Gross et al, 1966). Our finding that such dilatation may also be present in clinically unaffected members of a family supports the view that dilatation of the sarcoplasmic reticulum may well be the initial anatomical lesion.

It may be that the myotonia which occurs in periodic paralysis results from the greatly expanded intralumenal volume of the endoplasmic reticulum. This increase could interfere with removal of calcium from the muscle, a point of view supported by the presence of increased muscle calcium (Engel et al, 1965) and calcium (hydroxyapatite) in vacuoles in the sarcoplasmic reticulum of muscle from patients with periodic paralysis reported by others (Schutta and Armitage, 1969; Weller and McArdle, 1971). Since troponin inhibits muscle contraction and the calcium ion cancels this inhibition (Hoyle, 1970), such excesses of calcium could be responsible for the myotonia.

\section{REFERENCES}

Armstrong, F. S. (1962). Hyperkalemic familial periodic paralysis (adynamia episodica hereditaria). Annals of Internal Medicine, 57, 455-461.

Auböck, L. and Fladerer, H. (1970). Licht-und elektronenmikroskopische Untersuchungen von Muskeln bei Adynamia episodica hereditaria (Gamstorp Syndrom). Wiener Zeitschrift für Nervenheilkunde und deren Grenzgebiete, 28, 104-128.

Bergman, R. A., Afifi, A. K., Dunkle, L. M., and Johns, R. J. (1970a). Muscle pathology in hypokalemic periodic paralysis with hyperthyroidism. I. High resolution light microscopic study of a case. Fohns Hopkins Medical fournal, 126, 88-94.

Bergman, R. A., Afifi, A. K., Dunkle, L. M., and Johns, R. J. (1970b). Muscle pathology in hypokalemic periodic paralysis with hyperthyroidism. II. A light and electron microscopic study. Fohns Hopkins Medical fournal, 126, 100-118.

Biczyskowa, W., Fidzianska, A., and Jedrzejowska, H. (1969). Light and electron microscopic study of the muscles in hypokalemic periodic paralysis. Acta Neuropathologica, 12, 329-338.

Bradley, W. G. (1969). Adynamia episodica hereditaria. Clinical, pathologica! and electrophysiological studies in an affected family. Brain, 92, 345-378.

Brody, I. A. and Dudley, A. W., Jr. (1969). Thyrotoxic hypokalemic periodic paralysis. Archives of Neurology, 21, 1-6.

Danowski, T. S., Peters, J. H., Rathbun, J. C., Quashnock, J. M. and Greenman, L. (1949). Studies in diabetic acidosis and coma, with particular emphasis on the retention of administered potassium. Fournal of Clinical Investigation, 28, 1-9.

Danowski, T. S., Sabeh, G., Vester, J. W., Alley, R. A., Robbins, T. J., Tsai, C. T., Pazirandeh, M., and Sekaran, K. (1968). Serum CPK in muscular dystrophy and myotonia dystrophica. Metabolism, 808-817.

De Graeff, J. and Lameijer, L. D. F. (1965). Periodic paralysis. American fournal of Medicine, 39, 70-80.

Drager, G. A., Hammill, J. F., and Shy, G. M. (1958). Paramyotonia congenita. Archives of Neurology and Psychiatry, 80, 1-9.

Dunkle, L. M., Diggs, Ch.H., Bergman, R. A., and Johns, R. J. (1970). A light and electron microscopic study of a second case of hypokalemic periodic paralysis with hyperthyroidism. fohns Hopkins Medical fournal, 126, 225-236.

Egan, T. J. and Klein, R. (1959). Hyperkalemic familial periodic paralysis. Pediatrics, 24, 761-773.

Engel, A. G. (1966). Electron microscopic observations in primary hypokalemic and thyrotoxic periodic paralysis. Mayo Clinic Proceedings, 41, 797-808.

Engel, A. G. (1970). Evolution and content of vacuoles in primary hypokalemic periodic paralysis. Mayo Clinic Proceedings, 45, 774-814.

Engel, A. G., Lambert, E. H., Rosevear, J. W., and Fauxe, W. N. (1965). Clinical and electromyographic studies in a patient with primary hypokalemic periodic paralysis. American fournal of Medicine, 38, 626-640.

Eulenberg, A. (1886). Über eine familiäre, durch 6 Generationen verfolgbare Form congenitaler Paramyotonie. Neurologisches Centralblatt, 5, 265-272.

Fisher, E. R., Cohn, R. E., and Danowski, T. S. (1966). Ultrastructural observations of skeletal muscle in myopathy and neuro- 
pathy with special reference to muscular dystrophy. Laboratory Investigation, 15, 778-793.

Gamstorp, I. (1956). Adynamia episodica hereditaria. Acta Paediatrica, 45, Suppl. No. 108, 1-126.

Gamstorp, I., Hauge, M., Helweg-Larsen, H. F., Mjönes, H., and Sagild, U. (1957). Adynamia episodica hereditaria. American fournal of Medicine, 23, 385-390.

Gordon, A. M., Green, J. R., and Lagunoff, D. (1970). Studies on a patient with hypokalemic familial periodic paralysis. American fournal of Medicine, 48, 185-195.

Green, R., Rideout, D. F., and Shaw, M. L. (1961). Ergometry in the diagnosis of myasthenia gravis. Lancet, 2, 281-284.

Griggs, R. C., Engel, W. K., and Resnick, J. S. (1970). Acetazolamide treatment of hypokalemic periodic paralysis. Prevention of attacks and improvement of persistent weakness. Annals of Internal Medicine, 73, 39-48.

Gross, E. G., Dexter, J. D., and Roth, R. G. (1966). Hypokalemic myopathy and myoglobinuria associated with licorice ingestion. New England fournal of Medicine, 274, 602-606.

Hagedorn, H. C. and Jensen, B. N. (1923). Zur Mikrobestimmung des Blutzuckers mittels Ferricyanid. Biochemische Zeitschrift, 135, 46-58.

Harris, M. L., Jr. (1958). Serum aldolase determination as a routine laboratory procedure. American fournal of Medical Technology, 24, 99-105.

Henry, R. J., Chaimori, N., Golub, O., and Berkman, S. (1960). Revised spectrophotometric methods for the determination of glutamic-oxalacetic transaminase, glutamic-pyruvic transaminase, and lactic acid dehydrogenase. American fournal of Clinical Pathology, 34, 381-398.

Hochella, N. J. and Weinhouse, S. (1965). Automated assay of lactate dehydrogenase in urine. Analytical Biochemistry, 13, 322335.

Hofmann, W. W. and Smith, R. A. (1970). Hypokalaemic periodic paralysis studied in vitro. Brain, 93, 445-474.

Howes, E. L. Jr., Price, H. M., Pearson, C. M., and Blumberg, J. M. (1966). Hypokalemic periodic paralysis. Electronmicroscopic changes in the sarcoplasm. Neurology, 16, 242-256.

Hoyle, G. (1970). How is muscle turned on and off ? Scientific American, 202, No. 4, 85-93.

Ionescu, V., Radu, H., and Nicolescu, P. (1971). Ultrastructural changes in hypokalemic periodic paralysis. Revue Roumaine de Neurologie, 8, 419-425.

Jeune, M., David, M., and Villard, R. de (1970). Adynamie épisodique héréditaire: étude clinique et biologique d'une famille fournal de Médecine de Lyon, 51, 321-341.

Kind, P. R. N. and King, E. J. (1954). Estimation of plasms phosphatase by determination of hydrolysed phenol with aminoantipyrine. fournal of Clinical Pathology, 7, 322-326.

Klein, R., Egan, T., and Usher, P. (1960). Changes in sodium, potassium and water in hyperkalemic familial periodic paralysis. Metabolism, 9, 1005-1024.

Layzer, R. B., Lovelace, R. E., and Rowland, L. P. (1967). Hyperkalemic periodic paralysis. Archives of Neurology, 16, 455-472.

Macdonald, R. D., Rewcastle, N. B., and Humphrey, J. G. (1968). The myopathy of hyperkalemic periodic paralysis. An electron microscopic study. Archives of Neurology, 19, 274-283.

Macdonald, R. D., Rewcastle, N. B., and Humphrey, J. G. (1969). Myopathy of hypokalemic periodic paralysis. Archives of Neuro$\log y, 20,565-585$.

Mattingly, D. (1962). A simple fluorimetric method for the estimation of free 11-hydroxycorticoids in human plasma. Fournal of Clinical Pathology, 15, 374-379.

Odor, D. L., Patel, A. N., and Pearce, L. A. (1967). Familial hypokalemic periodic paralysis with permanent myopathy: clinical and ultrastructural study. Fournal of Neuropathology and Experimental Neurology, 26, 98-114.

Resnick, J. S. and Engel, W. K. (1967). Myotonic lid lag in hypokalaemic periodic paralysis. fournal of Neurology, Neurosurgery and Psychiatry, 30, 47-51.

Resnick, J. S., Engel, W. K., Griggs, R. C., and Stam, A. C. (1968) Acetazolamide prophylaxis in hypokalemic periodic paralysis. New England fournal of Medicine, 278, 582-586.

Schnaberth, G. and Summer, K. (1970). Uber Adynamia episodica hereditaria (Gamstrop). Wiener Zeitschrift für Nervenheilkunde und deren Grenzgebiete, 28, 81-103.

Schutta, H. S. and Armitage, J. L. (1969). The sarcoplasmic reticulum in thyrotoxic hypokalemic periodic paralysis. Metabolism, 18, 81-83.

Streeten, D. H. P., Dalakos, T. G., and Fellerman, H. (1971). Studies on hyperkalemic periodic paralysis. Evidence of changes in plasma $\mathrm{Na}$ and $\mathrm{Cl}$ and induction of paralysis by adrenal glucocorticoids. Fournal of Clinical Investigation, 50, 142-155.

Weller, R. O. and McArdle, B. (1971). Calcification within muscle fibres in the periodic paralyses. Brain, 94, 263-272.

Woolsey, R. M., Nelson, J. S., and Rossini, A. A. (1969). Paramyotonia and progressive neurogenic atrophy. Neurology, 19, 909914. 